\title{
PENGEMBANGAN MULTIMEDIA PEMBELAJARAN HUKUM AGRARIA PADA PROGRAM STUDI PENDIDIKAN KEWARGANEGARAAN UNIVERSITAS NEGERI YOGYAKARTA
}

\author{
Suripno \\ Program Studi PKn FIS UNY. Kampus Karangmalang Yogyakarta \\ email: suripno@uny.ac.id
}

\begin{abstract}
This study was aimed at: 1) producing an appropriate learning multimedia for agrarian laws in terms of the material and presentation aspects student responses, and 2) investigate the effectiveness of the developed multimedia to develop student learning outcomes. This was a research and development study. The results of the study were as follows. 1) Regarding the developed learning multimedia product: a) it had good quality in terms of the material aspect with a mean score of $4.10 ; b)$ it had good quality in terms of the presentation aspect with a mean score of 4.07; and c) the students' responses to the media attractiveness showed that the multimedia was attractive with a mean score of 3.82. 2) The effectiveness of the use of the developed learning multimedia to improve learning outcomes was indicated by the fact that: a) there was a score improvement (30.16\%) from a mean score of 51.50 in the pre-test to 73.75 in the post-test; and b) there was an improvement in mastery by $60 \%$ among 20 students, from five students (25\%) attaining mastery in the pretest to 17 students (85\%) attaining mastery in the posttest. Therefore, the multimedia for Agrarian Laws learning is appropriate to apply.
\end{abstract}

Keywords: Multimedia, Agrarian Laws, civic education

\section{PENDAHULUAN}

Tuntutan masyarakat terhadap peningkatan kualitas pendidikan merupakan prioritas utama yang perlu segera dipenuhi, lebih-lebih dalam era globalisasi. Untuk meningkatkan kualitas pendidikan diperlukan rancangan yang sebaikbaiknya, agar pendidikan berfungsi secara efektif dalam upaya peningkatan kualitas sumber daya manusia. Salah satu komponen penting dalam pendidikan adalah pendidik yang memiliki kompetensi sesuai dengan kualifikasi standar. Tanpa dimilikinya kompetensi tersebut, pendidik mustahil dapat melaksanakan perannya dengan baik, yang pada gilirannya akan mengakibatkan rendahnya kualitas hasil pendidikan.

Prioritas peningkatan kualitas pendidikan bagi Program Studi Pendidikan Kewarganegaraan dan Hukum Fakultas Ilmu sosial Universitas Negeri Yogyakarta, terlihat dalam visi yang dinyatakan dalam Kurikulum 2009 Prodi Pendidikan Kewarganegaraan dan Hukum Bab II huruf B butir 1 yakni: 
Terwujudnya program studi yang mampu melaksanakan pendidikan untuk menghasilkan output yang memiliki keunggulan kompetensi guna membentuk warga negara yang baik (good citizen) yang memiliki kesadaran moral, kesadaran politik dan kesadaran hukum dengan berlandaskan pada dasar negara Pancasila dan Undang-Undang Dasar 1945.

Output yang dihasilkan Program Studi Pendidikan Kewarganegaraan dan Hukum adalah tenaga kependidikan kewarganegaraan yang memiliki kompetensi pengetahuan di bidang moral, hukum dan politik serta memiliki keahlian atau keterampilan dalam melaksanakan profesinya. Tenaga kependidikan kewarganegaraan selain memiliki kemampuan akademik dan profesional juga dituntut untuk responsif terhadap berbagai masalah kehidupan bangsa dan negara serta perkembangan ilmu dan teknologi.

Masalah kehidupan bangsa dan negara dari dimensi hukum di antaranya masalah pertanahan atau agraria. Masalah pertanahan tidak akan habis selama masih berlangsung kehidupan di dunia ini, karena masalah tanah sangat berkaitan langsung dengan kebutuhan dasar manusia sebagai salah satu pelaku dari kehidupan ini. Kebutuhan dasar manusia tersebut antara lain: tempat tinggal, bahan makan, pakaian dan kebutuhan lainnya yang bersifat primer yang semuanya didapat dari tanah. Semakin meningkatnya populasi manusia sementara luas tanah tetap, akan menjadi pemicu perselisihan antar manusia. Perselisihan antar manusia sebagai akibat masalah pertanahan dapat diminimalisir melalui penanaman kesadaran dan ketaatan hukum di bidang keagrariaan. Usaha menyebarluaskan perlunya pemahaman, kesadaran dan ketaatan terhadap ketentuan hukum agraria dapat dilakukan melalui proses pembelajaran baik secara formal di sekolah maupun non formal.

Tujuan pembelajaran di sekolah merupakan cita-cita yang ingin dicapai dalam pelaksanaan pembelajaran dan bersifat normatif, karena dalam tujuan pembelajaran terdapat sejumlah nilai yang harus disampaikan dan ditanamkan pada diri siswa. Nilai tersebut akan menentukan dan memberi warna siswa dalam bersikap dan berperilaku dalam lingkungannya. Hasil belajar meliputi: 1) hal ihwal keilmuan dan pengetahuan, konsep atau fakta (kognitif), 2) hal ihwal personal, kepribadian atau sikap (afektif), 3) hal ihwal kelakuan, keterampilan atau penampilan (psikomotorik) (Sardiman, 2009: 29). Pembelajaran secara 
formal di sekolah merupakan peristiwa yang kompleks berlangsung di kelas. Pembelajaran terjemahan dari kata "instruction”, yang bisa dikatakan sebagai rangkaian kegiatan yang dirancang (desain pembelajaran) untuk tewrjadinya proses belajar siswa. Definisi tentang desain pembelajaran menurut Kanuka (2006: 3) sebagai berikut:

Instructional design is the art and science of creating an instructional environment and materials that will bring the learner from the state of not being able to accomplish certain tasks to the state of being able to accomplish those tasks. Instructional design is based on theoretical and practical research in the areas of cognition, educational psychology, and problem solving.

Dapat dikatakan bahwa desain pembelajaran merupakan seni dan ilmu tentang membuat lingkungan pembelajaran juga materi yang akan membawa peserta didik dari keadaan tidak mampu menyelesaikan tugas tertentu menjadi menyelesaikannya. Membuat desain pembelajaran itu berdasarkan pada teori dan praktik psikologi pendidikan dan pemecahan masalah. Kegiatan pembelajaran tidak sekadar menyampaikan materi kepada siswa peserta didik, tetapi penyampaian materi oleh pendidik harus dilandasi berbagai wawasan dan menggunakan berbagai keterampilan, oleh karena itu proses pembelajaran selain penyampaian materi perlu diperhatikan juga mengenai metode dan media pembelajaran. Metode mengajar adalah cara-cara menyajikan bahan pelajaran kepada siswa untuk tercapainya tujuan yang telah ditetapkan (Fathurrohman, 2007: 55). Pengertian ini menunjukkan bahwa metode mengajar yang dipergunakan pendidik sangat berpengaruh dalam mencapai tujuan atau sasaran belajar, sehingga pendidik harus mampu memilih dan menggunakan metode mengajar yang cocok untuk mencapai tujuan pembelajaran tertentu. Sedangkan media pembelajaran merupakan perantara atau alat untuk menyampaikan materi pembelajaran. Association for Educational and Communication Technology (AECT) memberi batasan bahwa media adalah semua bentuk dan saluran yang digunakan dalam proses penyampaian informasi (AECT, 1994: 201). Heinich (1996: 8) mengemukakan media pembelajaran adalah:

A medium (plural, media) is a channel of communication. Derived from the Latin word meaning "between" the term refers to anything that carries 
information between a source and a receiver. Examples include film, television, diagrams, printed materials, computers, and instructors.

Mata kuliah Hukum Agraria di Program Studi Pendidikan Kewarganegaraan dan Hukum memilki bobot 2 SKS. Pembelajaran mata kuliah ini akan memberikan pengetahuan, keterampilan dan penanaman kesadaran serta nilai di bidang hukum agraria. Harapannya akan memberi manfaat bagi mahasiswa dalam (1) menanggapi isu-isu pertanahan; (2) menilai secara kritis perkembangan hukum di bidang agraria; (3) menanamkan kesadaran untuk mentaati ketentuan hukum agraria. Hasil observasi di Lapangan menunjukkan bahwa proses pembelajaran hukum agraria di Program Studi Pendidikan Kewarganegaraan dan Hukum, khususnya dalam menjelaskan asas-asas ataupun sendi-sendi dan norma-norma pada materi hukum agraria, mahasiswa terlihat kurang termotivasi dalam mengikuti pembelajaran. Hal ini dapat dilihat dari kurangnya respon, perhatian, daya tarik dan minat mahasiswa dalam pembelajaran hukum agraria. Permasalahan ini timbul, berdasarkan hasil observasi disebabkan: (1) materi hukum agraria sebagian besar bersifat normatif; (2) penyampaian materi masih menggunakan pembelajaran konvensional yang memiliki beberapa kelemahan antara lain: pembelajaran tidak diawali dengan upaya memberikan daya tarik mahasiswa, misalnya penggunaan gambar, teks, gambar animasi, narasi audio; (3) media yang digunakan hanya media pembelajaran power-point masih bersifat informatif; (4) belum tersedianya multimedia pembelajaran interaktif misalnya media yang dilengkapi dengan alat kontrol atau navigasi yang mudah dioperasikan mahasiswa dan latihan soal sehingga mahasiswa dapat memilih apa yang dikehendaki untuk proses pembelajaran selanjutnya dan memperoleh umpan balik.

Keadaan ini menyebabkan suasana pembelajaran menjemukan, mahasiswa kurang termotivasi dalam mengikuti pembelajaran mata kuliah hukum agraria. Shcramm (1984: 3) menjelaskan bahwa tersedianya media dalam proses pembelajaran sangat penting dalam upaya merangsang perhatian anak, sehingga dapat meningkatkan motivasi belajar, membantu mempermudah pemahaman materi pelajaran yang diberikan yang akhirnya dapat meningkatkan hasil belajar. Dari pengertian ini menunjukkan bahwa media pembelajaran sangat penting untuk 
merangsang perhatian mahasiswa dalam mengikuti proses pembelajaran dan motivasi belajar mahasiswa dapat lebih meningkat, selanjutnya kualitas hasil belajar mahasiswa lebih meningkat.

Memperhatikan permasalahan tersebut di atas, perlu untuk mengembangkan dan membuat multimedia interaktif pembelajaran mata kuliah hukum agraria. Multimedia pembelajaran hukum agraria yang dihasilkan diharapkan dapat membantu dan memudahkan dalam memahami asas-asas atau sendi-sendi, normanorma hukum agraria dan meningkatkan hasil belajar bagi mahasiswa Program Studi Kewarganegaraan dan Hukum, Fakultas Ilmu Sosial, Universitas Negeri Yogyakarta.

Menurut Alessi dan Trollip (2001: 410) model pengembangan multimedia pembelajaran memiliki tiga karakteristik, yaitu standards, ongoing evaluation dan project management. Ketiga karakteristik ini melekat pada tiga tahap, yakni planning, design dan development. Standards meliputi penetapan standar kualitas produk yang akan dibuat. Ongoing evaluation adalah evaluasi yang melekat pada awal, tengah, atau akhir pengembangan produk. Evaluasi ini bersifat tidak formal dan dilakukan pada saat proses pengembangan masih berlangsung. Project management merupakan bagian dan proses penyelesaian terhadap perencanaan yang akan dilakukan, memonitoring secara konstan terhadap kemajuan pelaksanaan tiga tahap pengembangan (planning, design, dan development). Sesudah semua tahap untuk mengetahui tingkat kualitas produk dilakukan perlu dilaksanakan evaluasi (Alessi dan Trollip. 2001: 414). Evaluasi dilakukan dengan menggunakan format evaluasi, yaitu alat untuk memfokuskan perhatian pada kualitas yang akan dievaluasi. Sembilan aspek utama yang perlu dievaluasi adalah subject matter, auxiliary information, affective considerations, interface, navigation, pedagogy, invisible features, robustness dan supplementary materials.

Beberapa hasil penelitian yang mendukung berhasilnya penggunaan multimedia pembelajaran, diantaranya adalah:

1. Penelitian (1995) tentang "Pengembangan Computer-Assisted Instruction (CAI) Untuk Pelajaran Elektronika”, bahwa mahasiswa memberikan tanggapan sikap yang positif terhadap aspek-aspek program CAI yang meliputi: materi, 
tampilan, interaksi siswa, dan interaksi program, serta tingkat penguasaan materi elektronika meningkat.

2. Penelitian yang dilakukan oleh Jenks \& Springer (2002) dalam "A View of the Research on the Efficacy of CAI" menyimpulkan bahwa pembelajaran dengan $C A I$ lebih efektif dari pada pembelajaran konvensional. Penggunaan $C A I$ siswa bersikap positif dari pada pembelajaran konvensional. Pengaruh $C A I$ pada siswa, yaitu ke arah: pengendalian diri, kehadiran, motivasi mengerjakan tugas dengan tepat waktu dan kerja sama.

3. Penelitian yang dilakukan Indarsih (2006) tentang pengembangan multimedia pembelajaran berbasis komputer (MPBK) untuk pembelajaran Ilmu Pengetahuan Sosial (IPS) Kelas V Sekolah Dasar, disimpulkan bahwa penggunaan MPBK IPS kelas V di SD Klegung I Tempel dapat menaikkan nilai rata-rata sebesar 15,8 dari 48,6 menjadi 64,4 yang diketahui dari pre-test dan post-test. Beberapa hasil penelitian tersebut, dapat disimpulkan bahwa pembelajaran dengan multimedia memberi peranan sangat penting terhadap peningkatan kualitas proses pembelajaran.

Tujuan penelitian pengembangan ini adalah: 1). menghasilkan produk multimedia pembelajaran hukum agraria; 2). menguji kualitas multimedia yang dikembangkan ditinjau dari aspek materi, aspek media, respon mahasiswa dan hasil belajar mahasiswa. Multimedia yang dihasilkan dilengkapi dengan menu utama, petunjuk penggunaan, pendahuluan, materi, latihan, profil, dan sumber, animasi, background, musik, teks yang disesuaikan dengan materi sehingga lebih menarik.

Manfaat penelitian ini: 1). Bagi dosen sebagai upaya dalam mewujudkan suatu pembelajaran yang efektif dan menarik serta menjadi stimulus untuk mengembangkan profesi dosen. 2). Bagi mahasiswa untuk mempermudah pencapaian standar kompetensi, memotivasi mahasiswa untuk belajar mandiri, menjadi salah satu alternatif sumber belajar dan mendukung pembelajaran secara individual. 3). Bagi lembaga untuk mengatasi kurangnya media pembelajaran dan sebagai model media pembelajaran berbasis komputer

Istilah-istilah yang perlu dijelaskan dalam pengembangan multimedia pembelajaran hukum agraria sebagai berikut: 1). Pengembangan adalah suatu 
proses, cara atau perbuatan memodifikasi, mengolah dan menciptakan makna. Penelitian pengembangan merupakan suatu jenis penelitian yang tidak dimaksudkan untuk menguji teori tetapi merupakan penelitian yang berorientasi untuk menghasilkan atau mengembangkan dan memvalidasi sebuah produk. 2). Multimedia pembelajaran adalah sebuah produk yang dirancang dan dikembangkan dengan menggunakan beberapa program berbasis komputer yang digunakan untuk menyajikan materi pembelajaran, petunjuk penggunaan, latihan dan lainya. Produk ini didukung pula oleh unsur-unsur lain yang dapat membantu memfokuskan perhatian, misalnya adanya foto-foto, pewarnaan, musik dan animasi. 3). Hukum Agraria memiliki dua istilah yaitu hukum agraria dalam arti sempit dan hukum agraria dalam arti luas. Hukum agraria dalam arti sempit ketentuannya mengatur penguasaan hak atas permukaan bumi (tanah), sedang hukum agraria dalam arti luas ketentuannya mengatur penguasaan hak yang meliputi bumi, air dan ruang angkasa.

\section{METODE PENELITIAN}

Penelitian ini merupakan jenis penelitian dan pengembangan (Research and Development), yang menghasilkan produk pembelajaran berupa multimedia pembelajaran hukum agraria untuk mahasiswa Program Studi Pendidikan Kewarganegaraan dan Hukum Fakultas Ilmu Sosial, Universitas Negeri Yogyakarta. Desain yang digunakan adalah model Dick, Carey \& Carey (2007: 1), sedangkan dalam pengembangan media menggunakan model Luther. Desain evaluasi produk menggunakan evaluasi formatif, yang meliputi uji coba perorangan, uji kelompok kecil, uji coba lapangan.

Penelitian ini dilaksanakan pada bulan Desember 2011 sampai dengan Maret 2012, di Program Studi Pendidikan Kewarganegaraan Fakultas Ilmu Sosial, Universitas Negeri Yogyakarta. Subjek uji coba penelitian ini adalah mahasiswa semester III Program Studi Pendidikan Kewarganegaraan Fakultas Ilmu Sosial Universitas Negeri Yogyakarta, mahasiswa tersebut adalah mahasiswa yang sedang menempuh mata kuliah hukum agraria. Jumlah subjek uji coba sebanyak 28 mahasiswa dengan perincian: 3 mahasiswa untuk uji coba lapangan terbatas (perorangan), 5 mahasiswa untuk uji lapangan kelompok kecil, dan 20 mahasiswa untuk uji lapangan luas. 


\section{Prosedur Pengembangan}

Prosedur pengembangan dilakukan dalam empat tahapan pengembangan, yaitu:

1. Studi Pendahuluan, Studi pendahuluan dilakukan dalam dua kegiatan utama, yaitu studi pustaka dan studi lapangan.

2. Pengembangan desain pembelajaran:
a. Menentukan standar kompetensi;
b. Menentukan kompetensi dasar;
c. Melakukan analisis pembelajaran;
d. Merumuskan indikator;
e. Mengembangkan instrument penelitian;
f. Mengembangkan materi pembelajaran;
g. Menyusun strategi pembelajaran;
h. Merancang evaluasi.

3. Persiapan produk multimedia pembelajaran:
a. Menyiapkan materi yang dibutuhkan;
b. Membuat flowchart;
c. Membuat storyboard;
d. Membuat software pembelajaran;
e. Menyimpan software pembelajaran ke compact disk(CD).

4. Uji coba dan revisi produk:
a. Validasi ahli materi dan ahli media
b. Revisi produk atas dasar review ahli materi dan ahli media;
c. Uji coba produk (uji coba perorangan, uji coba kelompok kecil dan uji operasional/lapangan).

Revisi akhir produk, merupakan langkah terakhir dari tahapan evaluasi hasil produk, setelah dinyatakan layak maka produk ini akan di diseminasikan. Diseminasi dilakukan dengan cara: 1). Membuat laporan hasil penelitian dan pengembangan, untuk dipertahankan di depan penguji tesis. 2). Sosialisasi produk dilakukan dengan memberikan produk yang telah dikembangkan kepada Program Studi Pendidikan Kewarganegaraan dan Hukum 


\section{HASIL PENELITIAN DAN PEMBAHASAN}

Penilaian kualitas multimedia pembelajaran ditinjau dari aspek materi dan aspek tampilan (media) dapat dilihat pada Tabel 1, sebagai berikut:

\section{Tabel 1}

Kualitas Multimedia Pembelajaran Hasil Validasi

Oleh Ahli Materi dan Ahli Media

\begin{tabular}{|l|l|l|l|}
\hline No & Penilaian & Rata-rata Skor & Kriteria \\
\hline 1. & Ahli materi & 4.10 & baik \\
\hline 2. & Ahli media & 4,07 & baik \\
\hline Jumlah & $\mathbf{8 , 1 7}$ & \multirow{2}{*}{ Baik } \\
\hline Rata-rata skor & $\mathbf{4 , 0 9}$ & \\
\hline
\end{tabular}

Sumber: Data Diolah Peneliti, 2012

Berdasarkan tabel 1 menunjukkan bahwa kualitas multimedia pembelajaran dari aspek materi termasuk kriteria baik dengan rata-rata skor 4,10, aspek media (tampilan) baik dengan rata-rata skor 4,07. Secara keseluruhan kualitas multimedia pembelajaran ini termasuk kriteria baik yaitu dengan rata-rata 4,09. Hasil uji coba perorangan multimedia pembelajaran yang dikembangkan sudah baik. Aspek daya tarik pada uji coba perorangan menunjukkan rata-rata skor 21 menyatakan cukup menarik dan 9 menyatakan menarik. Rata-rata total skor 3,30 apabila dikonsultasikan dengan tabel kriteria penilaian aspek daya tarik termasuk kriteria menarik.

Skor yang diberikan oleh mahasiswa untuk aspek daya tarik pada uji coba kelompok kecil dapat dilihat pada tabel 2 berikut ini:

\section{Tabel 2}

Distribusi Frekuensi Skor Hasil Uji Coba Kelompok Kecil Aspek Daya Tarik

\begin{tabular}{|l|l|l|}
\hline \multicolumn{1}{|c|}{ Kriteria } & \multicolumn{1}{c|}{ Frekuensi } & \multicolumn{1}{c|}{$\%$} \\
\hline Sangat menarik & 0 & 0 \\
\hline Menarik & 16 & 32 \\
\hline Cukup menarik & 34 & 68 \\
\hline Kurang menarik & 0 & 0,00 \\
\hline Sangat kurang menarik & 0 & 0,00 \\
\hline
\end{tabular}

Sumber: Data Diolah peneliti, 2012

Aspek daya tarik pada uji coba kelompok kecil menunjukkan rata-rata skor 16 menyatakan menarik dan rata-rata skor 34 menyatakan cukup menarik. Rata- 
rata total skor 3,32 apabila dikonsultasikan dengan tabel kriteria penilaian aspek daya tarik termasuk kriteria menarik.

Skor yang diberikan oleh mahasiswa untuk aspek daya tarik pada uji coba lapangan dapat dilihat pada tabel 3 berikut ini:

Tabel 3

Distribusi Frekuensi Skor Hasil Uji Coba Lapangan Aspek Daya Tarik

\begin{tabular}{|l|l|l|}
\hline \multicolumn{1}{|c|}{ Kriteria } & \multicolumn{1}{c|}{ Frekuensi } & \% \\
\hline Sangat menarik & 28 & 14 \\
\hline Menarik & 108 & 54 \\
\hline Cukup menarik & 64 & 32 \\
\hline Kurang menarik & 0 & 0,00 \\
\hline $\begin{array}{l}\text { Sangat kurang } \\
\text { menarik }\end{array}$ & 0 & 0,00 \\
\hline
\end{tabular}

Sumber: Data Dioleh Peneliti, 2012

Aspek daya tarik pada uji coba lapangan menunjukkan bahwa sebagian menyatakan menarik dan cukup menarik dan hanya sebagian kecil yang menyatakan sangat menarik. Rata-rata total skor 3,82 apabila dikonsultasikan dengan tabel kriteria penilaian aspek daya tarik termasuk kriteria menarik. Hal itu menunjukkan bahwa multimedia pembelajaran tersebut menarik dan dapat digunakan untuk pembelajaran.

Untuk mengetahui efektivitas produk multimedia pembelajaran yang dikembangkan, maka uji coba lapangan diawali dengan menyelenggarakan pretest dan diakhiri dengan post-test. Tabel pre-test dan Post-test (terlampir) dapat diketahui bahwa hasil pre-test rata-rata 51,50, bila batas nilai kelulusan (tuntas) untuk mata kuliah hukum agraria adalah 70,00 maka dapat dilihat bahwa ada lima (25\%) mahasiswa yang dapat belajar tuntas, sedangkan lima belas (75\%) mahasiswa belum tuntas dalam belajarnya. Data tersebut menunjukkan bahwa secara keseluruhan pada hasil pre-test untuk materi tersebut belum mencapai kompetensi atau belum tuntas. Kemudian dari data post-test dapat diketahui bahwa tiga mahasiswa (15\%) yang tidak tuntas, 17 mahasiswa (85\%) yang tuntas.

Terjadi kenaikan rata-rata skor dari pre-test sebesar 51,50 menjadi 73,75 pada hasil post-test. Dari hasil tersebut dapat dikatakan bahwa multimedia pembelajaran yang dikembangkan efektif dan dapat digunakan dalam pembelajaran karena sudah lebih dari $75 \%$ mahasiswa dapat mencapai 
kompetensi. Dengan demikian maka produk multimedia pembelajaran hukum agraria layak untuk digunakan.

\section{KESIMPULAN}

1. Produk multimedia pembelajaran hukum agraria dikemas dalam bentuk CD (compact disc), dibuat menggunakan Power point dengan berbagai tampilan berupa teks, gambar, ilustrasi, animasi dan musik. Produk multimedia pembelajaran hukum agraria ini berisi tentang petunjuk, kompetensi dasar, indikator ketercapaian, materi tentang pengertian hukum agraria, objek agraria berdasarkan hukum agraria positif dan jenis-jenis pengertian hukum agraria. Produk ini telah dilakukan validasi ahli materi, validasi ahli media, uji coba perorangan, uji coba kelompok kecil dan uji coba lapangan dengan hasil sebagai berikut:

a. Ditinjau dari aspek materi termasuk kriteria baik, dengan rata-rata skor 4,10.

b. Ditinjau dari aspek tampilan termasuk kriteria baik dengan rata-rata skor 4,07 .

c. Tanggapan mahasiswa tentang daya tarik media termasuk kriteria menarik dengan rata-rata total skor 3,82.

2. Efektivitas produk multimedia pembelajaran hukum agraria dalam meningkatkan hasil belajar mahasiswa ditunjukkan pada peningkatan rata-rata skor pre-test dari sebesar 51,50 menjadi 73,75 pada hasil post-test. Dari 20 mahasiswa pada uji coba lapangan, tes yang dilakukan sebelum uji coba multimedia ada 5 mahasiswa yang mencapai ketuntasan (25\%) setelah mempergunakan multimedia ada 17 mahasiswa yang mencapai ketuntasan (85\%) dan ada 3 mahasiswa (15\%) yang tidak mencapai ketuntasan belajar, terjadi peningkatan ketuntasan $60 \%$.

\section{Saran}

Berdasarkan kesimpulan tersebut, maka dapat disampaikan saran-saran sebagai berikut:

1. Pengembangan multimedia yang lengkap sangatlah rumit dan kompleks, dalam penelitian pengembangan ini hanya merupakan bagian yang sangat kecil dari materi pengertian hukum agraria. Sebaiknya dalam pemanfaatan 
secara lisan/penugasan ditambahkan materi yang belum tercantum dalam multimedia yang dikembangkan, misalnya contoh-contoh gambar, video kejadian di lapangan dan untuk memperkaya mahasiswa diwajibkan mencari berita/artikel lain yang terkait dengan materi ini.

2. Multimedia pembelajaran yang dikembangkan, jika dimanfaatkan dengan baik akan dapat meningkatkan hasil belajar. Oleh karena itu meskipun multimedia ini masih sangat sederhana, dapat dimanfaatkan terutama di Program Pendidikan Kewarganegaraan dan Hukum FIS UNY, maupun pada pengguna lain.

3. Multimedia pembelajaran hukum agraria ini dapat dikembangkan lebih lanjut dengan cara menambah penjelasan, gambar, animasi, suara, video yang terkait dengan materi serta kasus-kasus atau peristiwa yang sering terjadi, agar nantinya multimedia yang dikembangkan menjadi lebih baik.

\section{DAFTAR PUSTAKA}

AECT. (1986). Definisi teknologi pendidikan. (Terjemahan Yusuf Miarso dkk) Buku asli The Definition of Educational Technology. Washington: Association for Educational Communication and Technology. (buku asli diterbitkan tahun 1994)

Alessi, S. M. \& Trollip, S. R. (2001). Multimedia for learning: methods and development. Boston: Allyn and Bacon.

Arsyad. A. (2007). Media pembelajaran Jakarta: Raja Grafindo Persada.

Dick, W., Carey, J. O. \& Carey, L. (2007). The systematic design of instruction ( $6^{\text {th }}$ ed.). Boston: Pearson.

Fathurrohman, P. \& Sobry. (2007). Strategi belajar mengajar. Bandung: Refika Aditama

Heinich, R., et. Al. (1996). Instructional media and technologies for learning New Jersey: Prentice Hall, Englewood Cliffs.

Indarsih. Y. (2006). Pengembangan media pembelajaran berbasis komputer untuk pembelajaran ilmu pengetahuan sosial Kelas V sekolah dasar. Tesis. Tidak diterbitkan. Yogyakarta: Program Pascasarjana UNY.

Jenks, M. S \& Springer, J.M. (2009). View of the research of Efficacy of CAI. Electronic Journal for the Integration of Technology In Education Vol.1 No. 2. Diambil pada tanggal 13/9/2013 dari http://ejite.isu.edu/volume 1 no. 2/Jenks.pdf. 
Jurusan PKnH tentang Kurikulum 2009 Program Studi Pendidikan Kewarganegaraan dan Hukum. Yogyakarta: Fakultas Ilmu Sosial dan Ekonomi Universitas Negeri Yogyakarta

Kanuka, H. (September 2006). Instructional design and e-learning: a discussion of Pedagogical content knowledge as a missing construct. Diambil pada tanggal 19 September 2013, dari http://www.ascilite.org.au/ajet/ejist/docs/vol9 no2/papers/kanuka.htm

Sardiman A.M. (2009). Interaksi dan motivasi belajar mengajar. Jakarta: Rajawali.

Shcramm, W. (1984). Media besar dan media kecil. (Terjemahan Abdul Gafur). Semarang: IKIP Press Semarang.

Sugiyono (2008). Metode penelitian pendidikan. Bandung: Alfabeta

Sukardjo. (2009). Evaluasi pembelajaran /perkuliahan bidang studi, Yogyakarta: Program Pascasarjana Universitas Negeri Yogyakarta.

Surjono. H.D. (1995). Pengembangan computer-assisted instruction (CAI) untuk pelajaran elektronika. [Versi elektronik]. Jurnal Kependidikan. No. 2 $(X X V)$ : 95-106. 